\title{
48. Simple Corals from the Sumagui Formation, the Philippine Islands.
}

\author{
By Hisakatsu YABE and Motoki EGUCHI. \\ (Comm. by H. YABE, M.I.A., June 12, 1941.)
}

The simple corals were collected by W. Hasimoto during his geological trips in the Philippines in 1937, and kindly donated to our Institute of Geology and Palaeontology, Tôhoku Imperial University, Sendai, where they are now stored.

Recent Philippine corals were studied since early times, and their best accounts appeared in a work by L. A. Faustino ${ }^{1}$, who studied the collection of the United States National Museum. In this work, aside from reef-builders, are included some solitary corals previously recorded on the collections of the surveying ships, "Challenger," "Siboga" and "Albatross."

Tertiary to Recent coral limestones are well developed in the Philippines, but records of fossil corals specifically named are few, the best probably being that of reef corals listed by Hasimoto ${ }^{2}$. Of fossils of simple corals, C. Semper, W. D. Smith and R. E. Dickerson inform us of Flabellum distinctum M. Edw. \& H., and Odontocyathus spiniger Mar. (as $F$. australe Mos., and O. coloradus Sm., respectively), from Point Colorado, Masbate; Flabellum distinctum, Balanophyllia sp., Fungia (Cycloseris) sp., Heterocyathus aequicostatus M. Edw. \& H. (as H. parasiticus Semp.), Heteropsammia ovalis Semp., from the Banisilan formation of Mindanao which is rich in simple corals; Heterocyathus aequicostatus (as H. philippinensis Semp.) from Luzon; and a few others. Our knowledge on fossil simple corals being so limited, the present material which is from Hasimoto's Sumagui formation of Sumagui, Bongabon, Mindoro, though not a rich one, deserves particular attention in having several species hitherto unknown as fossil from the Islands.

The Sumagui is rich in molluses and those collected by him are listed in his paper. This list also includes a simple coral, Flabellum transversale Mos. : it being correctly identified, is herein omitted. From geological observations and molluscan fauna, Hasimoto expressed the great similarity existing between his Sumagui formation and the Byôritu beds of Taiwan (at Hakusyaton, Sintikusyû); the two are considered by him to be almost contemporaneous.

Annexed is the list of the fossil simple corals from Sumagui discriminated by us, and Flabellum transversale is added; their recent distributions in the East Indies, Philippines and Japan with depth in meters is given.

1) L. A. Faustino: Madreporaria of the Philippine Islands. Philippine Bur. Sci., Vol. 22, 1927.

2) W. Hasimoto: Stratigraphy of the Philippines. Jubilee Publ. Comm. H. Yabe's 60th Birthday, 1939. 


\begin{tabular}{ll|c|c|c}
\hline & \multicolumn{3}{c|}{ Genus and species } & \multicolumn{3}{|c}{$\begin{array}{c}\text { Recent Distribution } \\
\text { (Depth in meters) }\end{array}$} \\
\cline { 3 - 5 } & & East Indies & Philippines & Japan \\
\hline 1) & Acanthocyathus grayi M. Edw. \& H. (1) & + & $?$ & 150 \\
2) Protolobophyllia cf. deshayesiana (Michelin) & $?$ & 13 & - \\
3) & Anthemiphyllia dentatus (Alcock)* & $?$ & $350-522$ & $75-306$ \\
4) Balanophyllia gigas Bruggemann* & $?$ & 90 & $116-234$ \\
5) Citharocyathus conicus Alcock* & 300 & 522 & $106-110$ \\
6) Heterocyathus aequicostatus M. Edw. \& H.* & + & $10-30$ & $102-658$ \\
$7)$ & Heteropsammia michelini M. Edw. \& H. & $22-75$ & $10-45$ & - \\
8) Trochocyathus hanzawai Yabe \& Eguchi* & - & - & - \\
& Flabellum transversale Moseley* & $50-100$ & 522 & $17-344$ \\
\hline
\end{tabular}

+ Depth-record unknown. ? Possibly present. - Absent, or at least not yet reported to occur. (1) Depth-record in Indian Ocean, 30-409 meters. * Species found in the Ryûkyû limestone of Kikai-zima, Kagosima-ken.

There is also a small rolled stock of a reef coral, Goniastrea and two fragments of Fungia. Of the listed solitary corals, T. hanzawai is a fossil species unknown in the recent fauna $P$. deshayesiana, $A$. dentatus, B. gigas, C. conicus, Heteroc. aequicostatus, Heterop. michelini and $F$. transversale are now living in the Philippines; $A$. grayi may also be found there alive.

$P$. deshayesiana, B. gigas, Heteroc. aequicostatus and Heterop. michelini are forms living in water not exceeding $50 \mathrm{~m}$ in the Philippine seas, though some often extend into deeper water; though $A$. dentatus, $C$. conicus and $F$. transversale have records from depth of $350-522 \mathrm{~m}$ in the Philippines, they can perhaps thrive in a depth less than $100 \mathrm{~m}$, as they do in the Japanese seas.

The rich molluscan fauna cited by Hasimoto from the Sumagui formation in his paper already referred to, suffices to assume the shallow water origin, perhaps $50-100 \mathrm{~m}$ or like, of this formation; the coral faunule likewise upholds this view.

The Sumagui formation with this coral faunule is, evidently, geologically very young, as all but one species are living, and of special mention is that six of its nine species also occur in the Ryûkû limestone, whose geological age is Plio-Pleistocene ${ }^{1)}$.

\section{Acanthocyathus grayi M. .Edw. \& H.2) Figs. 3a, 3b.}

(Reg. No. 65241)

One excellently preserved specimen. Corallum cuneiform, basally pointed, laterally narrowed to edge with 2 spines; radial costae feeble; septa 54, in three different sizes. Corallum $8 \mathrm{~mm}$ high, longer one of two spines $2 \mathrm{~mm}$ long, calice $5.5 \times 9 \mathrm{~mm}$ in size.

1) It is very noteworthy that the Sumagai formation, Byôritu beds and Ryûkyû limestone have Pecten naganumana Yokoyama in common; this species is one of the characteristic fossils of the Naganuma beds in the Kwantô region of Japan proper, of almost the same age.

2) Full reference of synonymy of this and the following species will be found in our forthcoming article, "Recent and Fossil Simple Corals of Japan," to be published in the Science Reports, Tôhoku Imperial University, Ser. II (Geology), 1941. 
Two large specimens of this species lately examined, from off Kii peninsula, Japan, agree in every respect with the figures and description of the type specimen by M. Edwards \& Haime, which is from an unknown locality. The specific identification of the fossil is made in comparison with the recent ones; the fossil is quite similar to the basal part of the type figures. This species was later reported by Alcock and Horst independently from the Indian Ocean and its third record is from Japan.

A. spiniger reported from Japan by $\mathrm{S}$. Kent is close to this species; juvenile specimens of the two may probably be indistinguishable from each other. Several specimens from the Pliocene of Tônohama, Kôti-ken once assigned with doubt by us to Trochocyathus laterocristatus of Felix (not M. Edw. \& H.) is, according to Umbgrove conspecific with the present species, in which the spines on lateral edges vary individually in development, sometimes reduced to mere crests; in the latter case this species resembles Premocyathas compressa Yabe et Eguchi which is common in the present seas and also occurs in the Neogene and Pleistocene rocks of Japan; in the latter species, however, corallum is much stronger and septa are more numerous, having pali and principal septa more than 12 .

Gerth distinguished his $A$. malayicus from $A$. grayi by having. regular hexameral arrangement of septa; Umbgrove, however, hold them specifically identical. In our materal (Japan) there are two types, one close to $A$. grayi and the other close to $A$. malayicus; the Philippine specimen seems to be a juvenile form of the former type. $A$. spinicarens Moseley from the Philippines ("Challenger" St. 210) is another species of this genus, quite distinct from A. grayi.

Citharocyathus conicus Alcock Figs. 4a, 4b. (Reg. No. 65242)

A rather large specimen; corallum $12 \mathrm{~mm}$ high, calice $8 \times 7.5 \mathrm{~mm}$ in size. Though its calice is firmly covered by sand and partly invisible, it shows all other characteristic features of this species and especially belongs to the type once distinguished under the name $C$. venustus Alcock, which is generally regarded as identical with $C$. concicus.

Distribution: Japan, Philippines and East Indies (390 m). Fossil : Ryûkyû limestone. This is the second find of this species in fossil state.

Trochocyathus ef. hanzawai Yabe \& Eguchi

Figs. 5a, 5b. (Reg. No. 65245)

A small, rather juvenile specimen, ca. $10 \mathrm{~m}$ high. Corallum turbinate, slightly curved, somewhat compressed, attached on a shell-fragment with small base; calice oval, $11 \times 8 \mathrm{~mm}$ in size, calicular fossa $5 \mathrm{~mm}$ deep. Septa thin, subequal in thickness, 48 in number, slightly exsert and subequal in elevation; wall not fully extending to calicular margin ; epitheca not preserved; outer surface covered by subequal fine and low granules usually arranged in series on more or less acute costae which are distinct near calicular margin.

Similar in the arrangement of septa and pali and in other features to the typical, conical specimens of this species. Precise specific identification impossible due to the immaturity of the specimen. 
Heterocyathus aequicostatus M. Edwards \& Haime

Figs. 6a, 6b. (Reg. No. 65244)

Two specimens; dimensions are :

$\begin{array}{lrr}\text { Base } & 11 \times 10 \mathrm{~mm} & 7.5 \mathrm{~mm} \\ \text { Diameter of calice } & 7 ” & 7 \% \\ \text { Height of corallum } & 5 " & 4 \%\end{array}$

Base finely granulated in larger specimen and smooth in smaller, otherwise similar. Quite similar to $H$. elberti Felix and also resembles $H$. parasiticus Semper in general shape. We agree perfectly with Umbgrove and others as to the specific identity of these two as well as such types as $H$. rousseaui M. Edw. \& H., philippinensis Semper, japonicus Marenzeller, rembangensis Gerth, pulchellus Rehberg and oblongatus Rehberg with the present species. Many interesting forms are found in association from the same stations and same depths, and from the same beds in the case of fossils, and there is no use to separate different species from this or to divide it into subspecies.

Distribution: Philippines, China Sea, Indian Ocean, Persian Gulf, South Africa, Japan. Fossil: Mindanao and Luzon (Semper); Sumagui, Mindoro; younger Tertiary and Pleistocene of Tiba-ken, Kanagawa-ken and Sizuoka-ken, Central Honsyû ; Ryûkyû limestone; Byôritu beds of Taiwan; Miocene to Pleistocene of Java, Ceram and Celebes.

Anthemiphyllia dentatus (Alcock) Figs. 1a, 1b. (Reg. No. 65243)

A single, disc-shaped specimen, $24 \mathrm{~mm}$ in diameter and $7 \mathrm{~mm}$ high. Characteristic dentate upper margin of septa well exposed on vertically split surface; columella spongy, no pali. Septal faces covered by fine granules. Costae rather widely spaced, precisely corresponding to septa, 77 in number.

A new family Anthemiphyllidae was proposed by T. W. Vaughan on this single genus, laying stress on the coarsely dentate upper margin of septa; otherwise it is similar to the Turbinolidae.

The first record of this species as fossil is from the Ryûkyû limestone of Kikai-zima, and the present occurrence is the second one.

Distribution: Philippines ; Pacific and Japan sea coasts of central and southwestern Japan. Fossil: Ryûkyû limestone.

\section{Protolobophyllia cf. deshayesiana (Michelin)}

Figs. 2a, 2b. (Reg. No. 65238)

While strongly dentate upper margin of speta as figured by Wells are completely demolished from our specimens, the acute echinules or denticles on costae are well preserved and these increase their size upward the corallum. Its turbinate, slightly compressed corallum is very similar in profile to that of Antilophyllia constricta (Brüggemann); the two, however, are easily distinguishable from one another, as costae are sharply dentated in the former and uniformly beamed in the latter. Corallum $35 \mathrm{~mm}$ in height, calice $60 \times 60 \mathrm{~mm}$ in size.

Almost indistinguishable from the large recent Philippine specimens treated by Wells; he established on this materal his new genus Acanthophyllia which apparently differs by its pointed base from Pro- 
tolobophyllia with broad, flat base. However, in Protolobophyllia japonica Yabe \& Sugiyama, the monotype, base is variable and one of its specimens from the type locality lately acquired possesses pointed base, thus being in no way different from Acanthophyllia.

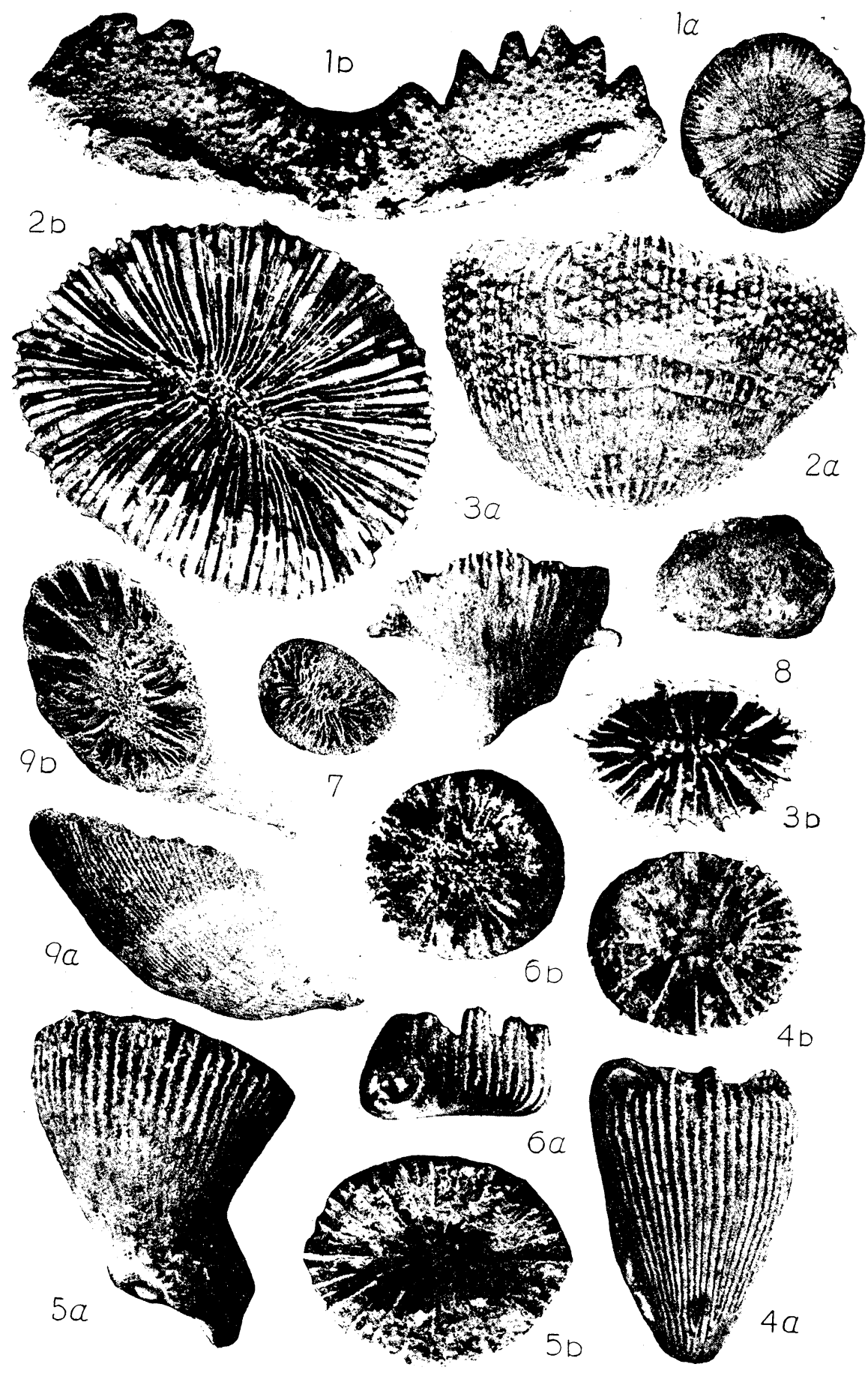



Sumagui.

Distribution: Philippines. Fossil : first record as fossil, from

Balanophyllia gigas Brüggemann Figs. 9a, 9b. (Reg. No. 65240)

A single cornuate corallum, torn at calicular margin and $40 \mathrm{~mm}$ high ; calice $25 \times 21 \mathrm{~mm}$ in size. It agrees well with the recent $B$. gigas from Japan of which we have many specimens and also is very similar to the figure of $B$. imperialis Kent which seems to be a juvenile specimen and probably that of $B$. gigas. A reexamination of the type of $B$. imperialis in direct comparison with $B$. gigas is in need for the decision of their specific identity.

Distribution: Japan, East Indies. Fossil : Ryûkyû limestone. $B$. imperialis Kent is from the elevated marl of Talaud.

Heteropsammia michelini M. Edwards \& Haime

Figs. 7, 8. (Reg. No. 65239)

$\begin{array}{lllrl}\text { Dimensions of four specimens } & 1 & 2 & 3 & 4 \\ \text { Longer diameter of calice } & 25 \mathrm{~mm} & 22 \mathrm{~mm} & 19 \mathrm{~mm} & 17 \mathrm{~mm} \\ \text { Shorter diameter of calice } & 15 " & 10 " & 9 " & 10 " \\ \text { Height of corallum } & 13 " & 17 " & 13 " & 10 "\end{array}$

The first and third specimens are more or less broken; all evidently belong to one and the same species, to which the original description of Heteropsammia michelini given by M. Edwards \& Haime passes precisely.

Distribution: China sea, Philippines, East Indies and Indian Ocean. Fossil : Konsuipin, Takao-syû, Taiwan (in ejecta of mud volcano); and the present locality.

\section{Explanation of Figures.}

Figs. 1a, $1 \mathrm{~b}$. Anthemiphyllia dentatus (Alcock). 1a, nat. size. $1 \mathrm{~b}, \times 5$.

Figs. 2a, 2b. Protolobophyllia cf. deshayesiana (Michelin). Nat. size.

Figs. 3 a, 3 b. Acanthocyathus grayi M. Edwards \& Haime. $\times 3$.

Figs. 4 a, 4 b. Citharocyathus conicus Alcock. $\times 3.5$.

Figs. 5 a, 5 b. Trochocyathus hanzawai Yabe \& Eguchi. $\times 3.5$.

Figs. 6 a, 6 b. Heterocyathus aequicostatus M. Edwards \& Haime. Nat. size.

Figs. 7, 8. Heteropsammia michelini M. Edwards \& Haime. Nat. size.

Figs. 9a, 9 b. Balanophyllia gigas Brüggemann. Nat. size. 